\title{
THE CURRENT STATE OF ARTIFICIAL REEFS IN LEBAH COASTAL WATERS, KARANGASEM, BALI: AN EVALUATION ON THE COASTAL RESOURCE REHABILITATION PROJECT
}

\author{
Isa Nagib Edrus") and Suprapto“")
}

\begin{abstract}
The study was conducted in May 2001 with aims to identify and examine changes the biotic condition of coastal resources. The study used dual approaches of old and new data collections followed by statistical test of Wilcoxon Rank Sum Test. The study focused on an affected area of the Coastal Village Development Project, particularly Lebah Coastal waters, Karangasem, Bali. The changes specifically related to artificial reef progresses as indicated by several indicators of marine biota, which have gradually grown in individual number, species numbers, kinds of benthic lifeforms, and their diversity during ten years. The statistical test at levels of $\alpha=0.010$ and 0.05 showed a high significant improvement of the benthic community of the artificial reefs. The means of benthic lifeform diversity values for 1991, 1994, and 2001 were $0.92 \pm 0.22,1.36 \pm 0.14$, and $1.95 \pm 0.39$, respectively. There was also a significant increase in reef fish diversity in vicinity of the artificial reefs corresponding to the same test, from an average of 1.74 in 1991 to 2.4 in 1994 and to 2.8 in 2001. The improvement of the artificial reef area condition may also be gauged by the abundance of Chaetodont species, an indicator organism expressed as Irian Jaya Reef Diversity Index. The mean of Irian Jaya Reef Diversity Index gradually increased from 4.9 in 1991 to 9.8 in 1994 and to 19 in 2001. Meanwhile the findings estimated that there was a decrease in coral percent covers of the nearby natural coral reefs.
\end{abstract}

KEYWORDS: artificial reefs, coral reefs, coastal water rehabilitation, marine organisms, Bali

\section{INTRODUCTION}

Marine tourism in Bali have being developed as an integral part of Indonesia's overall tourism strategy, which attempts to maximize its economic benefits and to provide recreational facilities for an increasingly urbanized domestic population. Hence, the recent public interest in the coastal zones has increased since the local and international investors and developers gravitated to shoreward maritime tourism industries. As a result of the economic benefits that could be derived from coastal resources, the coastal zones in this region teem with human settlements. About $60 \%$ of Bali's projected population (as much as 2.9 million) lives in the coastal areas where resources have been heavily exploited, especially between the 1970 s and 1990s when the tourism sector and associated socioeconomic developments increased (llyas et al., 1993). Therefore, both of the activities and their impacts during the last two decades might have been viewed positively or negatively.

A gradually accelerated rate of the environmental degradation due to tourism linked activities and the existing socio economic stresses have influenced regional policies. In this regard, the state has come up with a balanced regional development approach, specifically between the tourism sector and the agricultural sectors. In addition to improving the subsistence level of local communities and implementing coastal water rehabilitation, the last concern of the government which was reflected in the Great Outline of the State Direction, was to find viable income generating activities based on sustainable coastal resource utilization and integrated coastal management focused on conservation. The government placed emphasis on a harmony between the artisanal fishery and tourism industries because both depend on appropriate national management to sustain the health of the coral reef ecosystem as an economically valuable resource (llyas et al., 1993).

Unfortunately, some areas in Bali were not as environmentally endowed as others to support the development mentioned above. The coastal waters surrounding eastern Bali Island have been degraded since May 1, 1963, the year Mt Agung erupted. Black sand and other sediments left narrow area for coral growth. This made the coastal resources more vulnerable to accelerated rate of coral reef degradation in an area that was already naturally stressed.

It was for these reasons that a small scale coastal resource rehabilitation program was proposed locally in 1990. A collaboration of two government agencies was established to implement this program, which was supported by the country's budget plan. The Bali Provincial Fishery Service constructed some modules of artificial reefs made from discarded tires, and the Central Research Institute for Fishery Indonesia constructed concrete blocks with a particular shape. The aim of settling these modules in the Lebah Coastal water was not only to make substrates for growing reefs but also to make devices or shelters for aggregating fish that, finally, would affect the ecological recovery of the coastal water and economic life of the coastal inhabitants (CRIFI, 1994).

\footnotetext{
*) Institute Assessment for Agricultural Technology, Ambon, Maluku

Research Institute for Marine Fisheries, Ministry of Marine Affairs and Fisheries, Jakarta
} 
The artificial reef technology for degraded coastal water ecosystem recovery has both strengths and weaknesses. Understanding the involvement of the artificial reef in restoration ecology is useful for better planning in order to maximize the benefits derived from it and to minimize its negative consequences. Likewise, practitioners will discover that it, as a new paradigm in restoration ecology in Indonesia, has sought to incorporate different types of information. It resulted in gradual but important changes in the meaning and focus of the ecosystem growing process, especially for coral fish population and their indicator species related to the coral cover improvement.

The restoration technique by introducing of the artificial reef technology did not immediately bring about significant impacts on the environmental recovery of coastal waters and on socio-economic improvement of local communities. It needs longer time to mature and have impacts on succession processes of the coastal water resource recovery and desirable changes of local community's welfare

Hence, the restoration project must include a longterm monitoring and evaluation to guarantee verifiable criteria of measuring accomplishments either for biophysical or socioeconomic attributes. Shonman (1988) suggested that it is a critical aspect of any mitigation implementation agreement because this is the only way to verify if the developer is meeting the agreed upon terms. Most often, the only benefits that the environment receives come from the promised mitigations. Since these promises are part of the basis of approval of the development permit, they must be checked.

During a chronological period of the artificial reef successions, there is an opportunity to study the ecosystem development in relation to the rehabilitation effort. This is not only timely but also important, as it can clearly indicate whether or not the ameliorating process will continue. This study is to response the absence of project monitoring and evaluation activities. It focuses on an evaluation of the marine biota growth after ten years of implementing of the project. This study explored the following questions: what were the impacts of the process on the biotic conditions of the coastal waters? What were the appropriate indicators for this change?

The specific objectives of this study are to identify the biotic condition of coastal resources using selected indicators, including coral cover percentages, fish indicator species and fish reef diversity in vicinity of the artificial reefs and natural reefs.

\section{MATERIALS AND METHODS}

\section{Study Site}

The coastal waters of Tukadse and Jemeluk that were the project affected areas (Figure 1), are placed in Lebah Hamlet of Purwakerti Village under an administrative authority area of the Abang District of Karangangem County, eastern Bali.

\section{Data Collection}

Data collection was carried out in May 2001. A dual method approach was employed in the data collection such as on field measurement and secondary data uses. The latest was employed to compile the initial data related to similar indicators.

The line intercepts transect method using a $50 \mathrm{~m}$ transect length was conducted to determine natural coral reef condition, particularly the hard coral cover. The method was used to assess the benthic community of reefs using lifeform categories, which provide a morphological description of the reef community. The categories were recorded on data sheets by divers who swam along lines, which were placed roughly parallel to the reef crest or fringing reefs at certain depths of each selected site based on the initial study in 1991 or 1994. The method estimates the cover of an object or group of objects within a specified area by calculating the fraction of length of the line that is intercepted by the object (English et al., 1994).

Likewise, individual colonies of benthic community growing on the artificial reefs were measured to determine percent cover and diversity by using a quadrate sampling method.

The data of reef fish was obtained by using the visual census on the line transect in conjunction with recording benthic lifeform on the reef. The fish population was divided into three groups showing their status as well as indicator species, major species, and target species (English et al., 1994). The indicator species are mostly of the family Chaetodontidae. The major species are either ornamental or non ornamental fishes that are usually found in coral reefs both as a resident and as a crosser. The target species are fishes that are caught for consumption and/or sale by fishers.

\section{Data Analysis}

The computed values of the reef fish and benthic community on the artificial reefs derived from the Shannon-Weaver Diversity Index calculation. Coral conditions were analyzed and categorized based on the criteria of coral sound referring to percentage of transects with coral cover of excellent $>75 \%$; good $<75 \%->50 \%$; fair $<50->25 \%$; and poor $<25 \%$ (Chou, 1998). The LIFEFORM.EXE software recommended by the ASEAN-Australia Countries was used in the analysis of data. The software analyzed the fraction of length of the benthic or group of reef objects that were measured by the line intercept transect.

The Chaetodont abundance may reflect the 


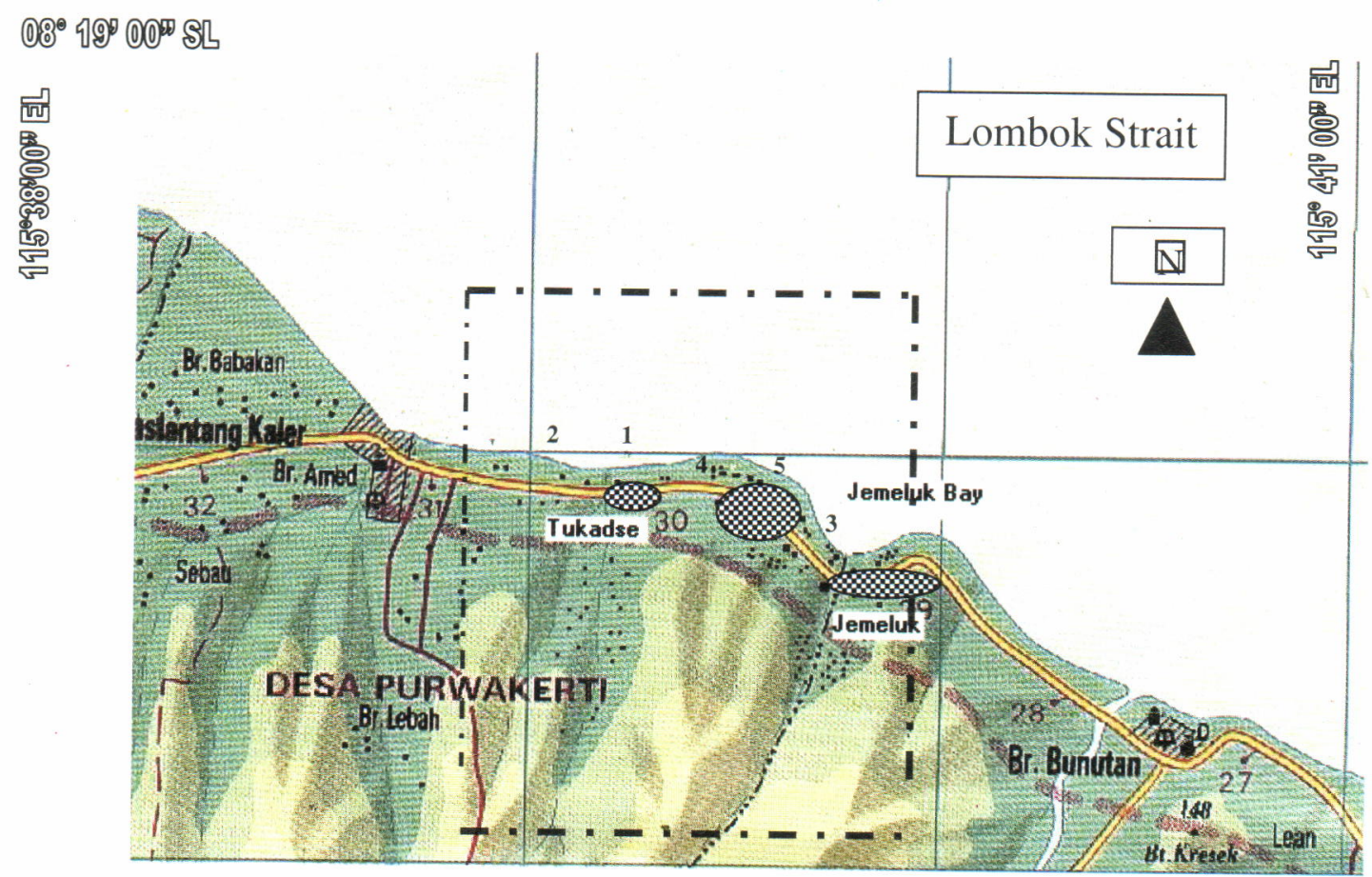

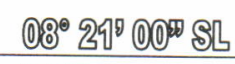

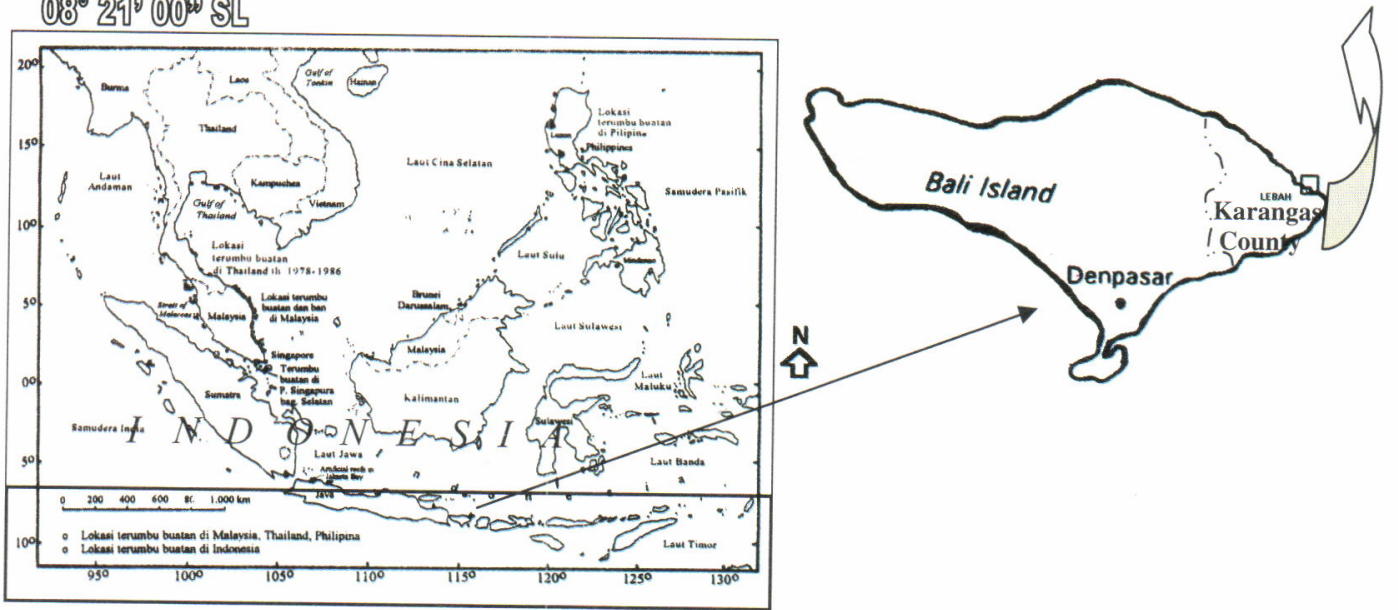

\section{Agenda}

Scale: $\quad 1: 40,000$

- - . The project affected area

1,2,3,4,5 Artificial reef sites / transect sites

Coral reefs areas

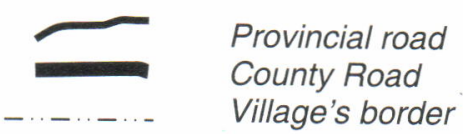

Housing

Figure 1. Purwakerti Village map showing the study site and project location.

relative health and diversity of coral reefs. Base on Irian Jaya Reef Diversity Index (IRDI=Cx/41x100) established by Nash (1989) to compare the reef diversity condition to species indicator attendance roughly, the species number of Chaetodont (Cx) presented at each study site can be an indication of local reef diversity condition. According to Nash (1989), a high position $(75+)$ on a regional Irian Jaya Reef Diversity Index scale suggests regions of exceptional overall species diversity and those important for reef conservation and production of commercially desirable fish species. A low (30-) regional Irian Jaya Reef Diversity Index number suggests poor diversity, reflecting low hard coral diversity and its associated fauna or a depleted fauna as a result of harvesting or environmental damage. Tentatively, individual reefs with an index of 45 or more could be considered very diverse, while an index of 25 or less suggests poor biodiversity. 
The significantly changes of selected indicator as mentioned above between before and after the project implementation (1991 and 2001) were examined by using Wilcoxon Rank Sum Test for independent sample.

\section{RESULTS AND DISCUSSION}

\section{Coral Cover Percentages}

The pioneer organisms in the artificial reefs were many algae, sponges, bryozoans, tunicates, amphipods, sand shrimps, small crabs, cnidarians, ascidians coralline algae and barnacles with a percent cover average of $21.52 \%$, mean diversity index $(H)$ of $0.90 \pm 0.22$ and mean density per $\mathrm{m}^{2}$ of $0.90 \pm 0.10$ (Table 1). These lifeforms dominated the artificial reefs in 1991. In 1994, there was a shift in the dominance of lifeforms, from the pioneer organisms to hard corals (acropore and non acropore) and other organisms with a percent cover average of 19.25. Possibly, the 1994 value was lower because of the absence of macro algae and the decrease in the population of sessile organisms. However, there was an increase in benthic community diversity $(1.36 \pm 0.14)$. It is interesting to note that the absence of macro algae in 1994 was noticed not only in the artificial reefs, but also in the natural reefs. Some local fishers also noted the absence of macro algae in natural reefs. The absence of macro algae was possibly due to the effect of flooding and the consumption by schools of fish, as mentioned by the local fishers, or due to the displacement by other sessile organisms like coralline algae. The displacement of the macro algae by other sessile organisms can be considered as a part of the succession of species in the community.

According to a result of a study (Pusat penelitian dan Pengembangan Perikanan, 1993) in the early years of the artificial reef be observed, the major sessile organisms were dominated by macro algae (Polycarpa aurata and Virgularia sp.) and barnacles (Balanus sp.) and then followed by Padina sp., Upuas, Eucema sp. A few hard corals started to grow with diameters of 0.5 to $8 \mathrm{~cm}$ and 1.4 to $6 \mathrm{~cm}$ length. These kinds included Favia sp., Porites sp., Goniopora sp., Monostrea sp., Acropora sp., Pocillopora sp., Seriatopora sp., Tubastrea sp., and Diploastrea sp. All of these organisms attracted other marine organisms to come in, such as crustaceans (ornamental shrimps and sand crabs), mollusks (Throchus, Cones, and Cyprae sp.), and echinoderms (Deadema sp. and Echinus esculatus). This shows that the areas, originally cleaned out, became productive.

In 2001, an additional 9 new lifeforms were noted among the artificial reefs (Figue 2). In this year, more lifeforms were observed among the artificial reefs than on the natural reefs (Table 1). The data show that the percent cover of the benthic community among the artificial reefs significantly increased from $21.52 \%$ in 1991 to $88.33 \%$ in 2001 . The total coral cover in the artificial reefs and natural reefs are comparable to that of 2001 (Table 1). This implies that the diversity of organisms among the artificial reefs could approximate the diversity among natural reefs within a decade.

The benthic community diversity in the artificial reefs increased from 0.92 in 1991 to 1.36 in 1994 and to 1.95 in 2001. A Wilcoxon rank sum test (Table 2) that was used to analyze the benthic diversity indexes among the artificial reefs showed that there was a low significant difference (at level of $\alpha=0.05$ ) for the diversity between 1991 and 1994 and between 1994 and 2001 as well. The low significant difference indicated that changing in the diversity for the short time period ( 4 or 7 years) in the artificial reefs was not shown enough, because, as mentioned by Fucik et al. (1984), recovery of coral reefs tends to be a long term process. According to Fucik et al. (1984) and Rinkevich \& Loya (1977), small scale localized destruction generally requires less than 10 years for recovery. Heavy destruction requires 10 to 20 years for full recovery. In line with this, the same test for this study showed a highly significant change in diversity indexes between 1991 and 2001 at level $\alpha=0.025$. It means that rehabilitation efforts have generated positive impacts on marine organisms, as reflected in the high diversity and density of benthic community among the artificial reefs.

The increased lifeform diversity among the artificial reefs in 2001 brought about an increase in the density of the colony of benthic communities among the artificial reefs. The density increased from 0.75 in 1994 to 7.86 in 2001. Some additional colonies of acropores (ACT, ACE), non acropores (CE, CF, CMR, and $C M E$ ), turf algae, and soft coral that were observed among the artificial reefs in 2001 contributed to the increased density among the artificial reefs in 2001 (Table 1). Other contributions also were given by the growing of branching corals, macro algae coralline algae, sponge, and other sessile organisms.

Although the artificial reefs had improved, the adjacent natural coral reefs were threatened due to anthropogenic activities and natural phenomena. The coral cover in Jemeluk Bay has been dwindling. Table 3 presents the results of different intercept transect surveys conducted in the bay in 1991, 1994, and 2001. The results show that the means of living hard coral cover were $53.7 \%$ (1991), $49 \%$ (1994), to $27.4 \%$ (2001). Findings of the 2001 survey show extensive areas of coral rubble and patches of standing dead hard corals that were partially or completely overgrown by turf algae (Figure 3 and Table 4). The 2001 level of turf algae cover on the natural reef areas varied from $30 \%$ to $66 \%$ (with a mean of $53.08 \pm 19.5$ ). 


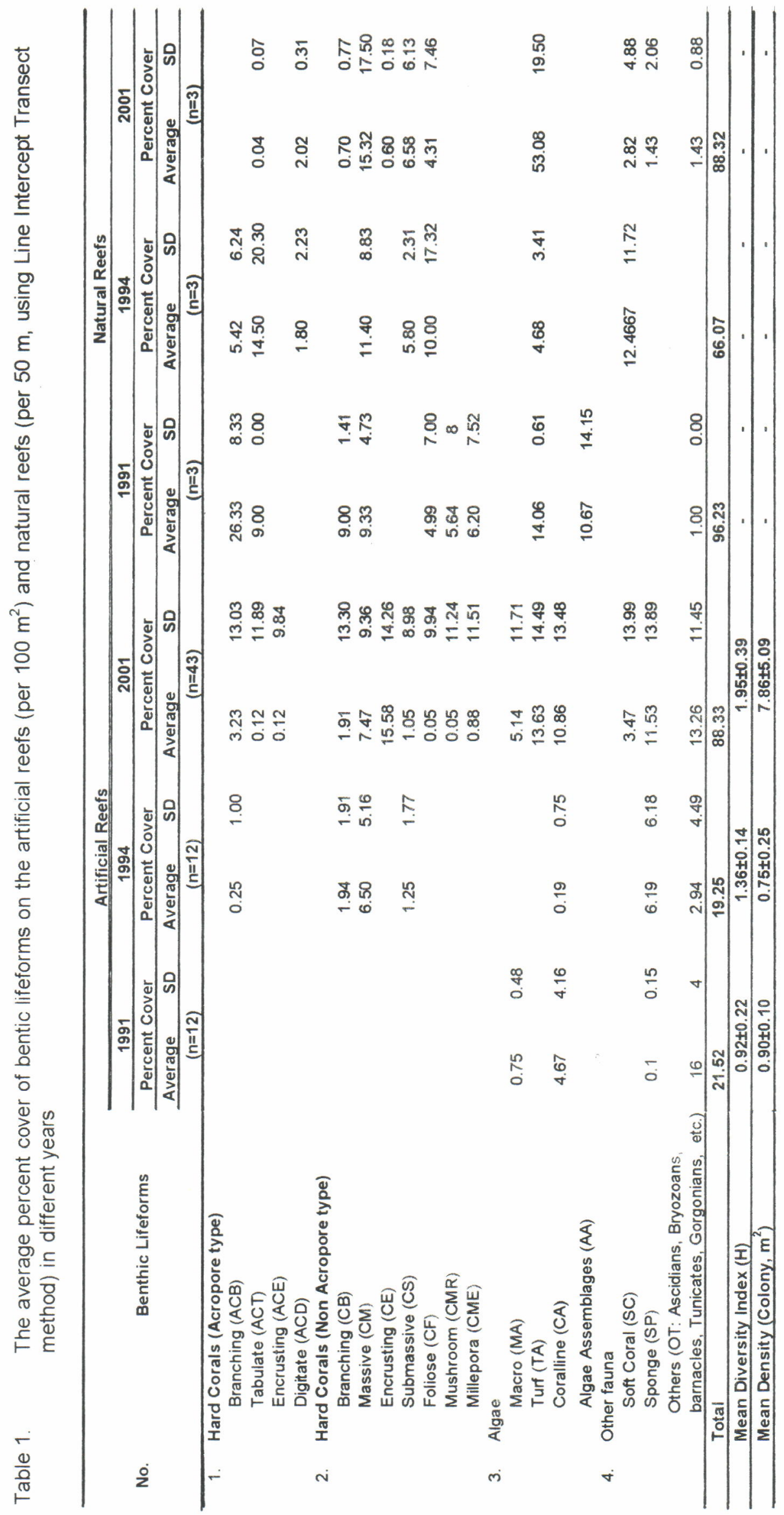


Table 2. Summary of Wilcoxon Rank Sum Test for independent sample of the artificial reefs benthic lifeform diversity index variables in different time

\begin{tabular}{|c|c|c|c|c|c|c|c|c|c|}
\hline \multirow[t]{2}{*}{ No. } & \multirow[t]{2}{*}{ Samples } & \multirow[t]{2}{*}{ Hypothesis ${ }^{*}$} & \multirow[t]{2}{*}{$\mathrm{T}_{\mathrm{a}}$} & \multirow[t]{2}{*}{$\alpha$} & \multirow[t]{2}{*}{$\mathrm{N}_{1}$} & \multirow[t]{2}{*}{$\mathrm{N}_{2}$} & \multirow[t]{2}{*}{$\mathrm{T}_{1}$} & $\begin{array}{c}\text { Rejection } \\
\text { Region }\end{array}$ & \multirow[t]{2}{*}{ Significance } \\
\hline & & & & & & & & $\mathrm{T}_{\mathrm{A}} \leq \mathrm{T}_{\mathrm{L}}$ & \\
\hline \multirow[t]{2}{*}{1.} & 1991 vs 1994 & $\mathrm{H}_{0}$ vs $\mathrm{H}_{\mathrm{a}}$ & 7 & 0.025 & 3 & 4 & 6 & Accepted & \\
\hline & & & & 0.050 & & & 7 & Rejected & Low \\
\hline \multirow[t]{2}{*}{2.} & 1994 vs 2001 & & 13 & 0.025 & 4 & 5 & 12 & Accepted & \\
\hline & & & & 0.050 & & & 13 & Accepted & Low \\
\hline \multirow[t]{2}{*}{3.} & 1991 vs 2001 & & 6 & 0.025 & 3 & 5 & 6 & Rejected & \\
\hline & & & & 0.050 & & & 7 & Rejected & High \\
\hline
\end{tabular}

${ }^{*} \mathrm{H}_{0}=$ Probability distribution of samples corresponding to the old measurement of benthic lifeform diversity index (A) and new measurement of benthic lifeform diversity index (B) are identical (There is no a significant change on the lifeform diversity during the definite years).

$\mathrm{H}_{\mathrm{a}}=$ The probability distribution for $\mathrm{B}$ lies above (to the right of) to the $\mathrm{A}$ (There is a significant change on the lifeform diversity during the definite years).
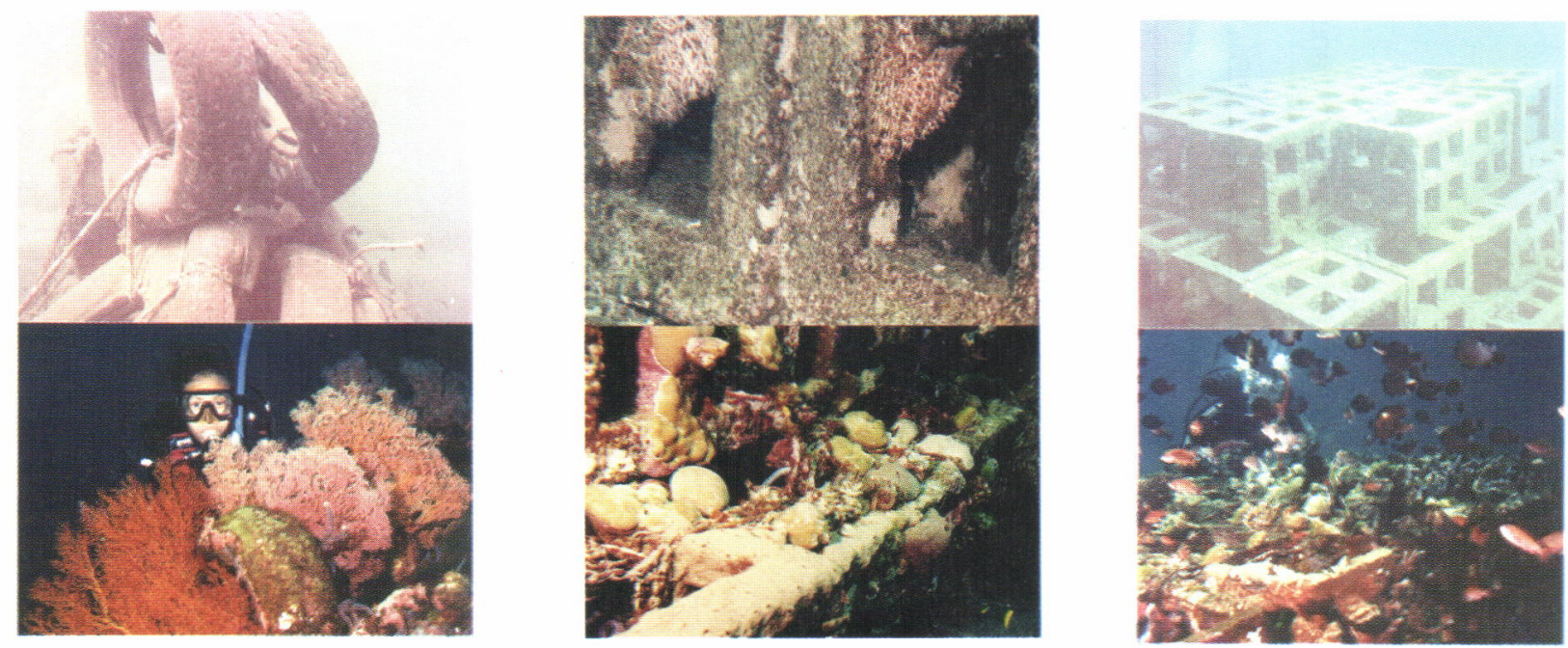

Figure 2. The new recruitment of benthic lifeforms on the artificial reefs at Lebah Coastal waters in different years.

Table 3. Comparison of percent cover of natural hard corals and their health conditions by different sites and years at Lebah coastal waters, Bali

\begin{tabular}{|c|c|c|c|c|c|c|c|}
\hline \multirow{3}{*}{ No. } & \multirow{3}{*}{ Locations } & \multicolumn{6}{|c|}{ Coral Health } \\
\hline & & \multicolumn{2}{|c|}{$1991^{*}$} & \multicolumn{2}{|c|}{$1994^{* *}$} & \multicolumn{2}{|c|}{$2001^{* * *}$} \\
\hline & & Percent & Scales & Percent & Scales & Percent & Scales \\
\hline 1. & 1 & 69 & good & 67.3 & good & 17.28 & poor \\
\hline 2. & 2 & 71 & excellent & 26.45 & fair & 50.56 & good \\
\hline 3. & 3 & 21 & poor & 53 & good & 14.4 & poor \\
\hline 4. & Mean & 53.7 & good & 49 & fair & 27.4 & fair \\
\hline
\end{tabular}

** = Using permit from ir. Bangkit, a Bali Provincial Fishery Service Staff

$* \star * *$ Primary Data 


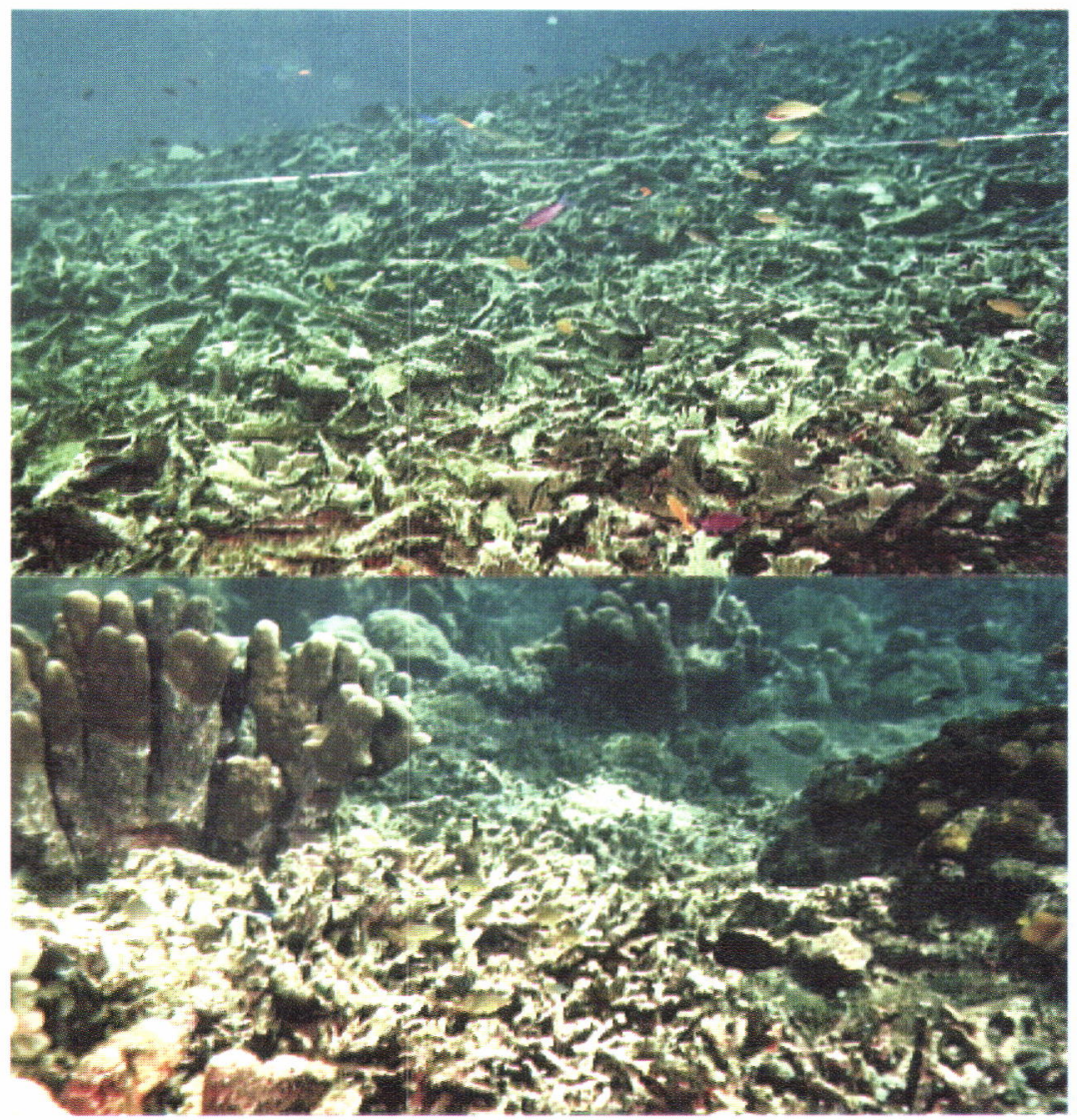

Figure 3. The damage areas at Jemeluk Coastal water identified as a result of diver steps.

Usually, the phenomena of turf algae covered coral (standing but dead) is a result of anthropogenic activities such as sedimentation, cyanide fishing, blast fishing, dragging boat anchors, and natural factors such as starfish predation, storm waves, hurricanes, and EI Niño (Chou, 1998). There was also observed bleaching in the bay. The 1997 to $1998 \mathrm{El}$ Niño (elevated sea surface temperature) was believed to have been responsible for bleaching large areas of corals across the Indonesia seas, including Tulamban, Amed, Nusa Penida, and Nusa Lambongan, Bali (Brown \& Suharsono, 1990; Chou, 1998; Jamani et al., 2000).

\section{Reef Fish Diversity and Density}

Table 5 presents reef fish diversity indexes and density (number per $\mathrm{m}^{2}$ ) in both artificial and natural reefs. Details in family, genus and species are presented in Table 6 and Appendix. The diversity index was used to evaluate the changes in fish population in the vicinity of the artificial reefs and to compare the diversity of fish population between the artificial reefs and natural reefs.

According to Kakimoto (1979), a trend of fish diversity in the vicinity of artificial reefs usually follows growth of attached organisms on the artificial reef. $\mathrm{He}$ observed that after 20 years, appearance of the artificial reefs changed due to high intensity of the growths of the attached organisms together with associated organisms that make the food chain or web in the artificial reefs.

The results of Wilcoxon rank sum test at level of $\alpha=0.025$ and 0.050 (Table 7 ) shows that fish diversity between 1991 and 1994 and between 1991 and 2001 in vicinity of the artificial reef was highly significant different. The significant differences between the fish diversity in the artificial reefs between 1991 and 1994 as well as 1991 and 2001 could be due to the succession process in artificial reefs as mentioned by Kakimoto (1979). As succession proceed in the artificial reefs, more benthic lifeforms that settle on the substrates attract more fish to come. Some of the lifeforms serve as food for the fish. The diversity of lifeforms in the artificial reefs increased from 0.90 in 1991 to 1.95 in 2001 (Table 1). This increase may lead to the increase in fish diversity.

The same test shows that there was no a significant difference of reef fish diversity between the artificial reefs and natural reefs in 2001. The relationship of fish diversity between the artificial reefs and natural reefs may be related to the observation that both have comparable diversities. These comparative diversities may have similar attracts. 
Table 4. Percent covers of the coral reefs by different sites and years in Lebah Coastal waters, Bali, Karangasem County, Indonesia

\begin{tabular}{|c|c|c|c|c|c|c|c|c|c|c|c|}
\hline \multirow{3}{*}{ No. } & \multirow{3}{*}{$\begin{array}{l}\text { LIFEFORM } \\
\text { CATEGORY }\end{array}$} & \multirow{3}{*}{ CODE } & \multicolumn{3}{|c|}{ SITES } & \multicolumn{3}{|c|}{ SITES } & \multicolumn{3}{|c|}{ SITES } \\
\hline & & & 1 & 2 & 3 & 1 & 2 & 3 & 1 & 2 & 3 \\
\hline & & & \multicolumn{3}{|c|}{1991} & \multicolumn{3}{|c|}{1994} & \multicolumn{3}{|c|}{2001} \\
\hline \multirow[t]{7}{*}{1.} & Hard Corals & & & & & & & & & & \\
\hline & (Acropores types) & & 38.00 & 42.00 & 17.00 & 18.30 & 1.85 & 45.00 & 0.00 & 0.00 & 0.43 \\
\hline & Branching & $A C B$ & 29.00 & 33.00 & 17.00 & 12.50 & 0.75 & 3.00 & & & 0.00 \\
\hline & Tabulate & ACT & 9.00 & 9.00 & & 5.80 & & 37.70 & & & 0.12 \\
\hline & Encrusting & ACE & & & & & & & & & \\
\hline & Submassive & ACS & & & & & & & & & \\
\hline & Digitate & $A C D$ & & & & & 1.10 & 4.30 & & & 0.31 \\
\hline \multirow[t]{10}{*}{2} & Hard Corals & & & & & & & & & & \\
\hline & (Non Acropore types) & & 31.00 & 20.00 & 4.00 & 49.00 & 24.60 & 8.00 & 17.28 & 50.56 & 13.97 \\
\hline & Branching & $\mathrm{CB}$ & 8.00 & 10.00 & & & & & & 1.24 & 0.15 \\
\hline & Massive & $\mathrm{CM}$ & 11.00 & 13.00 & 4.00 & 10.60 & 20.60 & 3.00 & 1.28 & 34.92 & 9.75 \\
\hline & Encrusting & CE & & & & & & & 0.40 & 0.76 & 0.65 \\
\hline & Submassive & CS & & & & 8.40 & 4.00 & 5.00 & 2.68 & 13.64 & 3.42 \\
\hline & Foliose & $\mathrm{CF}$ & 7.00 & 2.00 & & 30.00 & & & 12.92 & & \\
\hline & Mushroom & CMR & 2.00 & & & & & & & & \\
\hline & Millepora & $\mathrm{CME}$ & 3.00 & 4.00 & & & & & & & \\
\hline & Haliopora & $\mathrm{CHL}$ & & & & & & & & & \\
\hline \multirow[t]{2}{*}{3} & $\begin{array}{c}\text { Dead Scleractinia } \\
\text { Dead coral }\end{array}$ & & 0.00 & 0.00 & 0.00 & 0.00 & 0.00 & 0.00 & 0.00 & 0.00 & 0.00 \\
\hline & (With algal Covering) & DCA & & & & & & & & & \\
\hline \multirow[t]{6}{*}{4} & Algae & & 29.00 & 24.00 & 75.00 & 6.60 & 0.75 & 6.70 & 66.00 & 30.66 & 63.70 \\
\hline & Macro & MA & & & & & & & & & \\
\hline & Turf & TA & 2.00 & 22.00 & 72.00 & 6.60 & 0.75 & 6.70 & 66.08 & 30.66 & 62.50 \\
\hline & Coralline & $\mathrm{CA}$ & & & & & & & & & \\
\hline & Halimeda & $\mathrm{HA}$ & & & & & & & & & \\
\hline & Algal Assemblage & AA & 27.00 & 2.00 & 3.00 & & & & & & 1.20 \\
\hline \multirow[t]{5}{*}{5} & Other fauna & & 1.00 & 1.00 & 1.00 & 7.20 & 25.90 & 4.30 & 0.74 & 11.30 & 5.00 \\
\hline & Soft Coral & $\mathrm{SC}$ & & & & 7.20 & 25.90 & 4.30 & & 8.46 & \\
\hline & Sponge & SP & & & & & & & 0.06 & 0.44 & 3.80 \\
\hline & Zoanthids & ZO & & & & & & & & & \\
\hline & Others & OT & 1.00 & 1.00 & 1.00 & & & & 0.68 & 2.40 & 1.20 \\
\hline \multirow[t]{5}{*}{6} & Abiotic & & 1.00 & 4.00 & 3.00 & 18.90 & 46.90 & 36.00 & 15.90 & 7.48 & 16.90 \\
\hline & Sand & S & 1.00 & 4.00 & 3.00 & 4.40 & 3.50 & 6.00 & 15.90 & 7.48 & 10.60 \\
\hline & Rubble & $\mathrm{R}$ & & & & & & 23.00 & & & \\
\hline & Silt & SI & & & & & & & & & \\
\hline & Rock & RCK & & & & 14.50 & 43.40 & 7.00 & & & 6.30 \\
\hline
\end{tabular}

Between 1991 and 2001, the density of reef fish in the artificial reefs has considerably increased, from 0.87 in 1991 to 17.07 in 2001 (Table 5). Trend in reef fish density could be due to the on going succession process, as mentioned above. The increase in benthic community diversity led to the increase in fish density in the same years among the artificial reefs. Meanwhile, fish density was higher among artificial reefs than in natural reefs in 2001 . Fish, particularly in schools, usually moved freely from one area to another, so that this result could also indicate that fish have a strong affinity to artificial reefs that may lead to influx of fish from nearby natural reefs. Studies on behavior of fish in vicinity of artificial reefs placed around natural reefs showed that fish have an affinity for artificial reefs (Kakimoto, 1984). Possibly, the artificial reefs have additional sources of food and shelter.

\section{Fish Indicator Species}

The growing uses of the species indicator corresponding to coral soundness determination showed that it was a simple method in coral reef monitoring. It is not only for experts, but also for non specialists. For example, the presence of Chaetodonts in coral reef water may reflect the relative health and diversity of hard coral (Nash, 1989). 


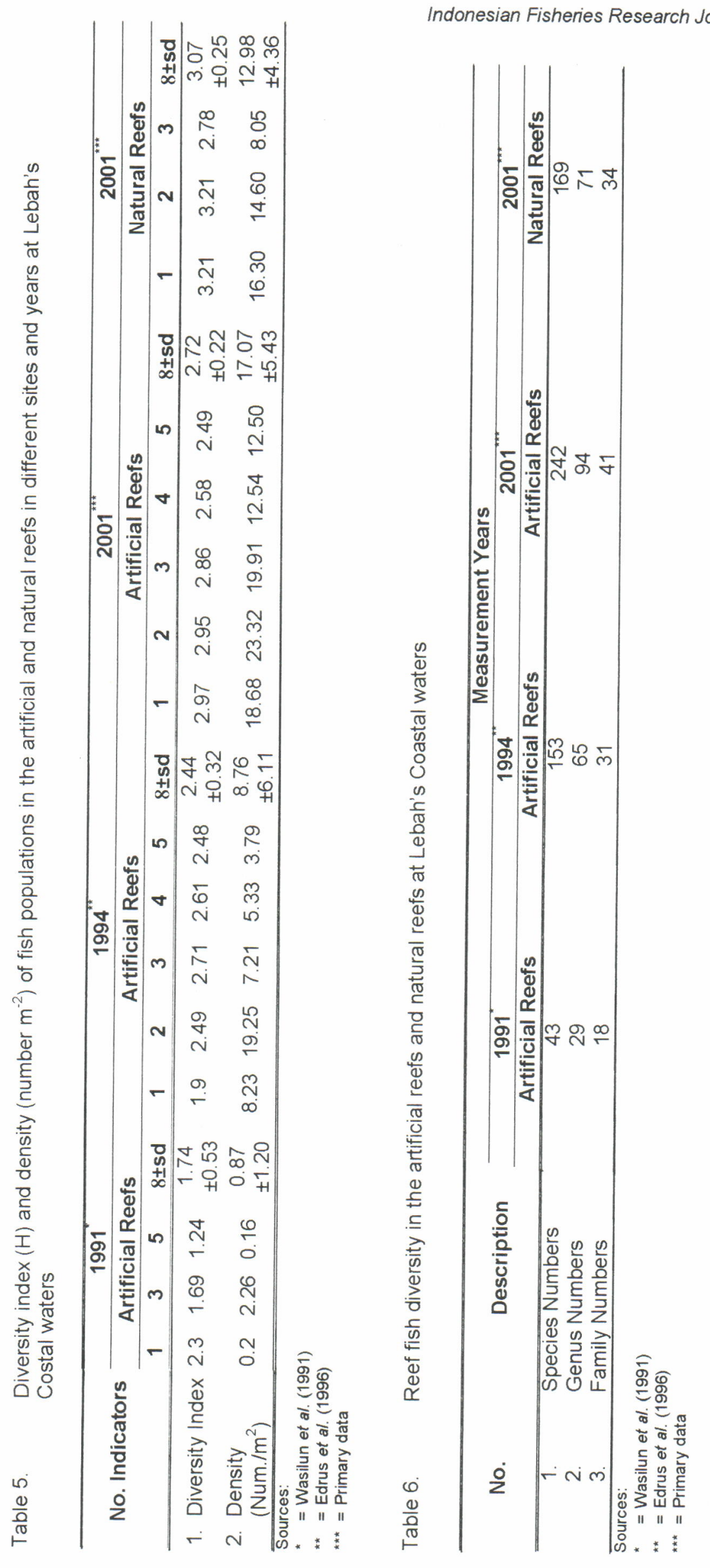


Chaetodonts are major noticeable polyp feeders among reef's ichthyofauna (Mackay, 1994). This species are easy to identify and to census individually because they have definite territories and they are often found in pairs. In addition, they are often employed as better measures for health of coral reefs (Rees, 1977). In general, Iow Irian Jaya Reef Diversity Index (below 35\%) of Chaetodonts may indicate poor diversity of hard cover (Nash, 1989). The idea to use Chaetodonts as indicator in determining the soundness of reefs was derived from a study conducted by Reese (1977). Reese (1977) noted that two kinds of polyp feeders (Chaetodon trifascillis and Chaetodon trifasciatus) responded to changes of coral reef soundness in terms of abundance, distribution, and behavior

Table 7. Summary of Wilcoxon Rank Sum Test for independent sample of fish diversity index variables in different years

\begin{tabular}{|c|c|c|c|c|c|c|c|c|}
\hline \multirow[t]{2}{*}{ No. Samples } & \multirow[t]{2}{*}{ Hypothesis") } & \multirow{2}{*}{$\mathrm{T}_{\mathrm{a}}$} & \multirow{2}{*}{$\alpha$} & \multirow{2}{*}{$\mathrm{N}_{1}$} & \multirow[t]{2}{*}{$\mathrm{N}_{2}$} & \multirow{2}{*}{$\mathrm{T}_{1}$} & $\begin{array}{l}\text { REJECTION } \\
\text { Region }\end{array}$ & \multirow{2}{*}{ Significance } \\
\hline & & & & & & & $T_{A} \leq T_{L}$ & \\
\hline \multirow[t]{2}{*}{ 1. 1991 vs 1994} & $\mathrm{H}_{\mathrm{o}}$ vs $\mathrm{H}_{\mathrm{a}}$ & 6 & 0.025 & 3 & 5 & 6 & Rejected & Highly \\
\hline & & & 0.050 & & & 7 & Rejected & \\
\hline \multirow[t]{2}{*}{ 2. 1994 vs 2001} & & 19 & 0.025 & 5 & 5 & 18 & Accepted & \\
\hline & & & 0.050 & & & 19 & Rejected & Lowly \\
\hline \multirow[t]{2}{*}{ 3. 1991 vs 2001} & & 6 & 0.025 & 3 & 5 & 6 & Rejected & Highly \\
\hline & & & 0.050 & & & 7 & Rejected & \\
\hline \multirow{2}{*}{$\begin{array}{l}\text { 4. } 2001 \text { AR vs } \\
2001 \mathrm{NR} \\
\end{array}$} & & 18 & 0.025 & 3 & 5 & 6 & Accepted & Highly \\
\hline & & & 0.050 & & & 7 & Accepted & \\
\hline
\end{tabular}

\section{Remark:}

${ }^{*} \mathrm{H}_{0}=$ Probability distribution of samples corresponding to the old measurement of fish diversity index (A) and new measurement of fish diversity index $(B)$ are identical (There is no a significant change on the fish diversity during the definite years)

$\mathrm{H}_{\mathrm{a}}=$ The probability distribution for $\mathrm{B}$ lies above (to the right of) to the $\mathrm{A}$ (There is a significant change on the fish diversity during the definite years)

NR $=$ Natural reef

$A R=$ Artificial reefs

The succession process in terms of hard coral growth on artificial reefs may be indicated by the abundance of chaetodont species. Table 8 shows the IRDI values in different years. Although the IRDI rates observed in different years were still very low as compared to the regional Irian Jaya Reef Diversity Index scale, that is, $35 \%$, there is an increasing trend in Irian Jaya Reef Diversity Index rates among all sites, particularly between 1991 and 2001 (Table 8). This suggests that their gradual increases are of great importance in evaluating a transient condition of hard coral growth. The increasing trend in IRDI rates from 1991 to 2001 follows the increasing trend in the diversity of hard coral cover among the artificial reefs.

Table 8. The Irian Jaya Reef Diversity Index of butterfly fish (Chaetodontidae) used to determine the relative health and diversity of artificial reefs

\begin{tabular}{|c|c|c|c|c|c|c|c|c|c|c|c|c|c|c|}
\hline \multirow{4}{*}{ No } & \multirow{4}{*}{ INDEX } & \multicolumn{13}{|c|}{ MEASUREMENT YEARS } \\
\hline & & \multirow{2}{*}{\multicolumn{3}{|c|}{$\frac{1991}{\text { Sites }}$}} & \multicolumn{5}{|c|}{$1994^{* *}$} & \multicolumn{5}{|c|}{$2001^{\pi * x}$} \\
\hline & & & & & & & Sites & & & & & Sites & & \\
\hline & & 1 & 3 & 5 & 1 & 2 & 3 & 4 & 5 & 1 & 2 & 3 & 4 & 5 \\
\hline 1. & IRDI (\%) & 4.9 & 7.3 & 2.4 & 2.4 & 7.3 & 4.9 & 4.9 & 29.3 & 22 & 14.6 & 14.6 & 9.8 & 34.2 \\
\hline 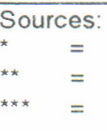 & $\begin{array}{l}\text { Wasilun et al. (1991) } \\
\text { Edrus et al. (1996) } \\
\text { Primary data }\end{array}$ & & & & & & & & & & & & & \\
\hline
\end{tabular}

The relationship between coral cover percentages and chaetodont diversity showed a high significaint correlation at several studies (Edrus \& Syam 1998; Hutomo et al., 1985). These studies showed that the rising Irian Jaya Reef Diversity Index rates in all sites were related to the existing growth of hard coral, indicating a transient succession by artificial reef organisms to arrive at a climax condition. Under this condition, the hard coral together with other reef fauna organisms would attain optimum growth corresponding to the area of substrates available on the artificial reefs. Likewise, the Chaetodonts would settle in favorable areas and expect that their abundance and species number would grow in the future. In this study, there is still space for on going coral growth 


\section{CONCLUSION}

The specific impacts of the rehabilitation effort on biotic parameters of coastal resources that can be concluded address to the following major points:

1. Positive environmental changes in vicinity the artificial reefs enable to be a basic premise of success of the project in bringing about tangible impacts on the local coastal resources.

2. The major areas of biotic-parameter changes in vicinity of the artificial reefs include increases in coral percent cover, reef fish diversity and density, and chaetodontid abundance indexes.

3. The statistical tests to above respective variables at levels of $\alpha=0.010$ and 0.05 shows high significant improvement of the marine biota condition between 1991 and 2001.

4. There was a considerable indication of dwindling coral cover of the natural coral reefs.

\section{ACKNOWLEDGEMENTS}

The authors wish to tank the following people and organizations for their assistance in the research: Imam Suprihanto, S.Si., Drs. Henri D. Berri, I Ketut Ardita, S.Sos., Ir. Bangkit, Dinas Perikanan Tingkat I Bali, Dinas Perikanan Tingkat II Karangasem Bali, and Departemen Kelautan dan Perikanan.

\section{REFERENCES}

Brown, B. E. \& Suharsono. 1990. Damage and recovery of coral reefs affected by EI Niño related seawater warming in the thousand Islands, Indonesia. Coral Reefs 8:163-170.

Chou, L.M. 1998. Status of Southeast Asian Coral Reefs. In Status of coral reefs of the world: 1998. C. Wilkinson (Ed). Sida-Australian Institute of Marine Science-ICLARM Publ., Quensland, Australia, $79 \mathrm{p}$.

CRIFI. 1994. A Technical guidance for artificial reef management. Seri Pengembangan Hasil Penelitian Perikanan No.PHP/KAN/PT.29/1994, CRIFI, Agency for Agricultural R \& D, Dept. of Agricultural Ministry.

Edrus, I. N. \& A. R. Syam. 1998. Distribution of the Chaetodontidae in coastal waters of Ambon Island and their role in determination coral reef condition. Jurnal Penelitian Perikanan Indonesia (Journal Indonesia Fisheries Resorce) Vol.IV (3): $1-10$.
English, S., C. Wilkinson, \& V. Baker.1994. Survey manual for tropical marine resources. Australian Institute of Marine Science, Townsville. Australia.

Fucik, K. W., T. J. Bright, \& K. S. Goodman. 1984. Measurements of damage, recovery, and rehabilitation of coral reefs exposed to oil. In Restoration of habitats impacted by oil spills. J. Cairns, Jr. \& A. L. Buikema, Jr. (Eds). Butterworth Publishers, Boston.

Hutomo, M., Suharsono, \& S. Martosewojo. 1985. Indonesian ornamental fishes and coral reef sustainability. Paper for Indonesian Ornamental Fishes Seminar, Jakarta, October 12, 1985 (Unpublished).

Ilyas, S., Wasilun, K. Wagiyo, Sarjana, Murniyati, \& F. Cholick. 1993. Integrated management for coral reefs and artificial reefs in the coastal water of Karangasem District, Bali. Work Paper presented for the Yield Dissemination of Fishery Research and Development, in Bali, November 27, 1993. CRIFI-Agency for Agricultural R \& $D$, Jakarta, Indonesia.

Jamani, N. P., M. Nurlidiasari, \& K. S. Putra. 2000. Bleaching Phenomena in amed waters, Bali: Monitoring 1997-1999. Procidding Lokarya Pengelolaan dan Iptek Terumbu Karang Indonesia, Jakarta, 22-23, Nopember 1999. Lembaga IImu Pengetahuan IndonesiaCOREMAP, Jakarta, $146 \mathrm{p}$.

Kakimoto, H. 1979. Artificial reefs in Japan Sea Coastal regions. Procidding $7^{\text {th }}$ Japan-Soviet Joint Symposium Aquaculture, September 1978, Tokyo.

Kakimoto, H. 1984. Studies on the behavior of fishes in the vicinity of artificial reefs in the coastal waters of Niigata. Prefecture. Niigata Prefecture Fish. Exp. Sta., Niigata, Japan.

Mackay, K. T. 1994. Butterfly fishes of the family Chaetodontidae at Hila Reef. Ambon, Maluku, Indonesia. Fakultas Perikanan Universitas Pattimura (Unpublished).

Nash, S. V., 1989. Reef diversity index survey method for non spacialist. Tropical Coastal Area Management Vol.4 (3): 14-17.

Pusat Penelitian dan Pengembangan Perikanan, 1993. The enhancement project for fishery living habitat. Project Scientific Report, 1992-1993. CRIFI, Jakarta (Unpublished). 
Reese, E. 1977. Coevolution of coral and coral feeding fishes of family Chaetodontidae. Proceeding of the third International Coral Reef Symposium 1: 267-274.

Rinkevich, A. A. \& Y. Loya. 1977. Harmful effects of chronic oil pollution on a Red Sea scleractinian coral population. In Proceeding of the Third
International Coral Reef Symposium, Vol.II: Geology, D. L. Taylor (Ed), Miami: Rosenstiel School of Marine and Atmospheric Science.

Shonman, D. 1988. Resolving coastal restoration conflicts: Environmental protection guanrantees. In Environmental restoration: Science and strategies for restoring the earth. J. J. Berger (Ed). Island Press, Washington, D. C. 
Indonesian Fisheries Research Journal Vol.11-2005

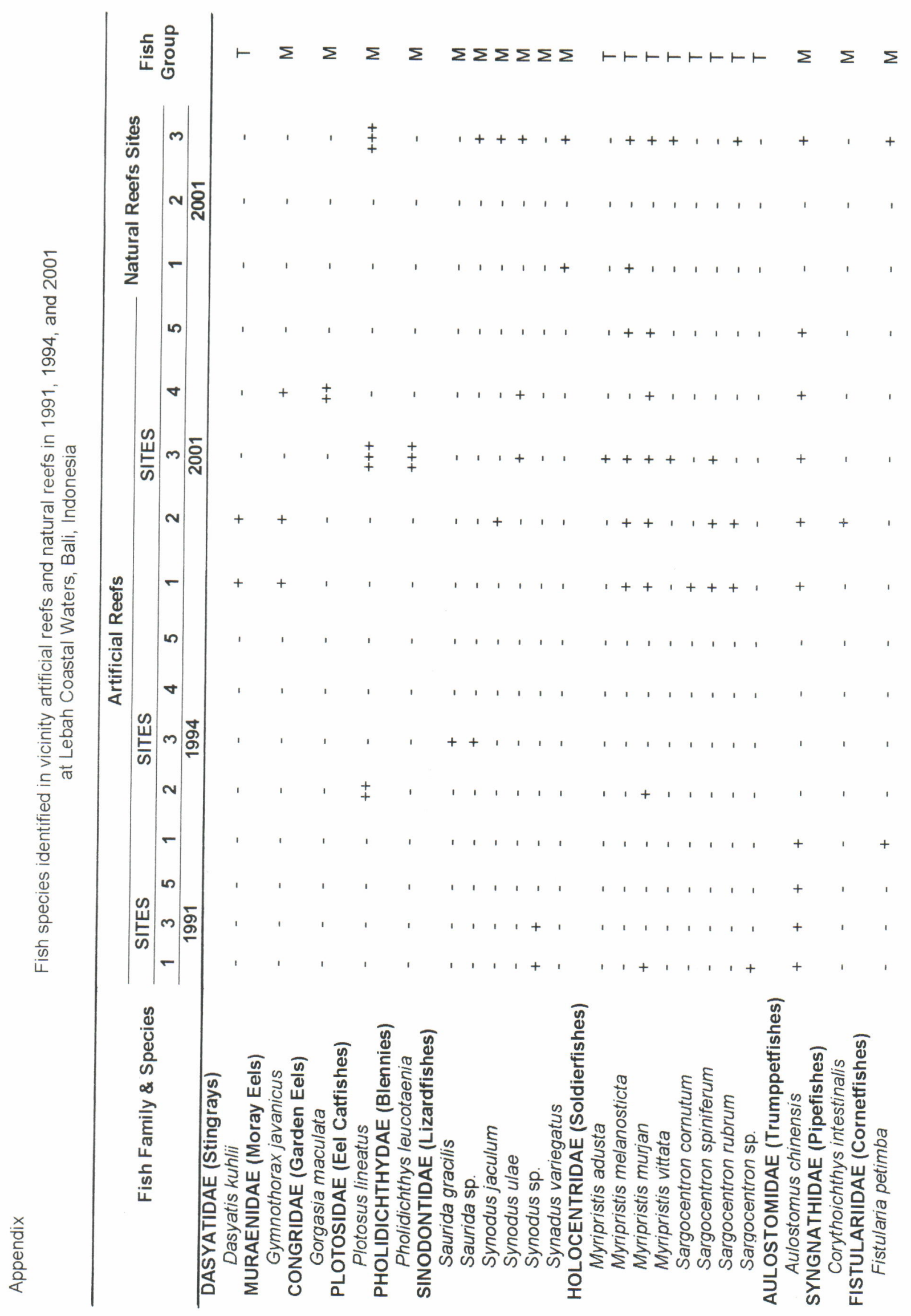


Isa Nagib Edrus and Suprapto

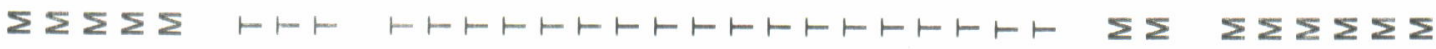
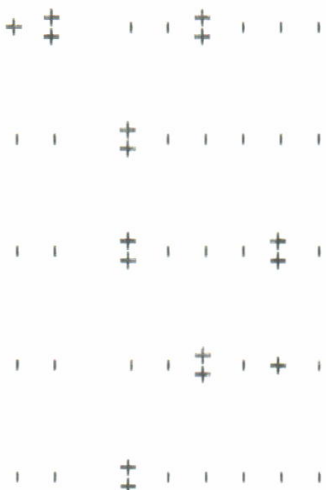

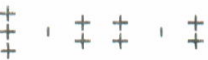

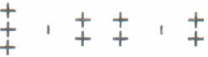

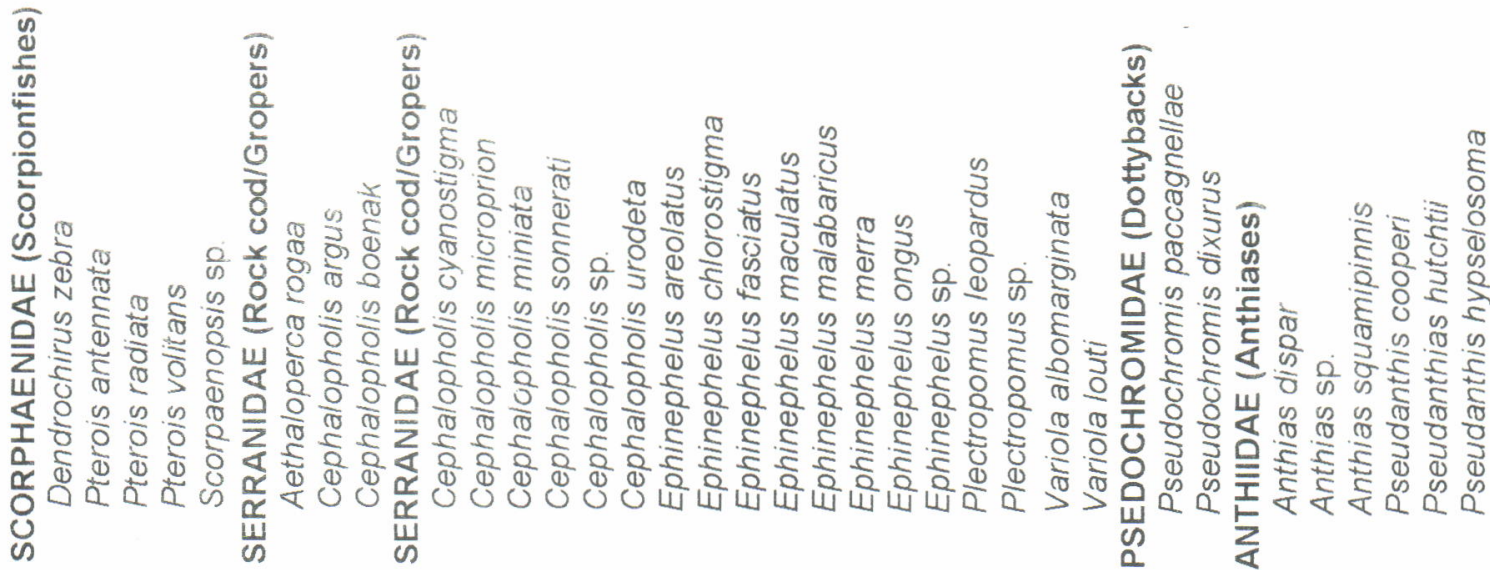




$$
\Sigma \Sigma \Sigma
$$

\section{$+$}

$$
+
$$$$
+
$$

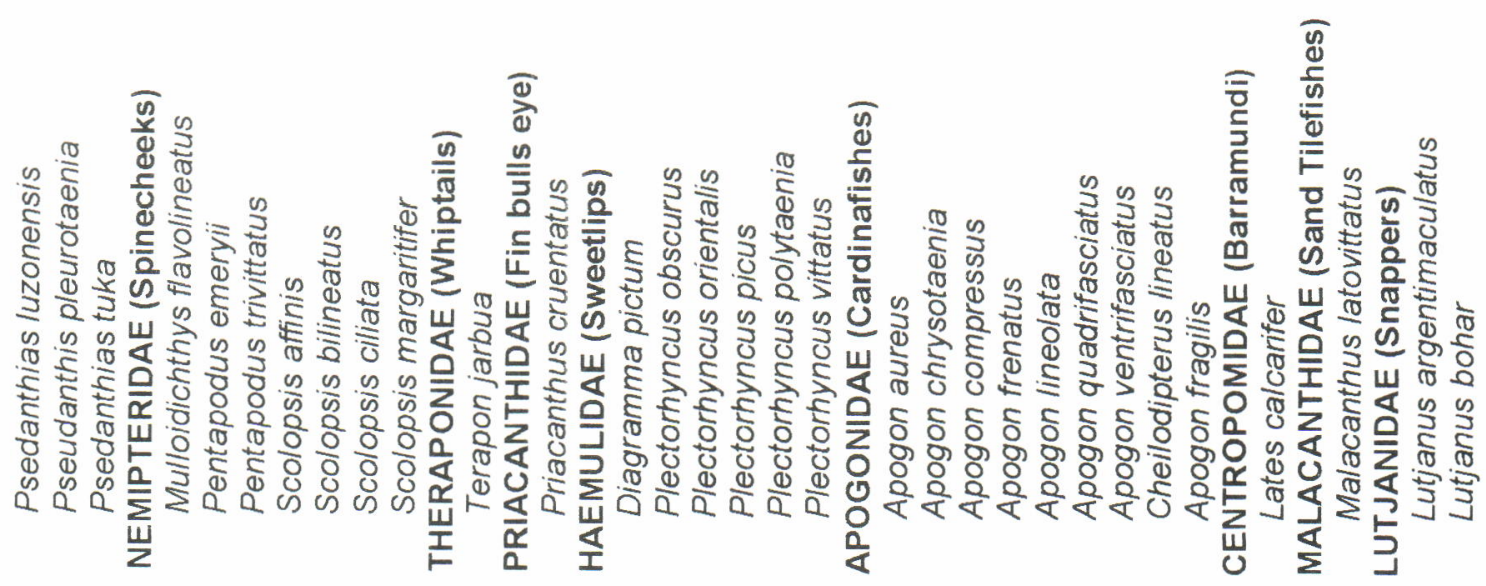


Isa Nagib Edrus and Suprapto
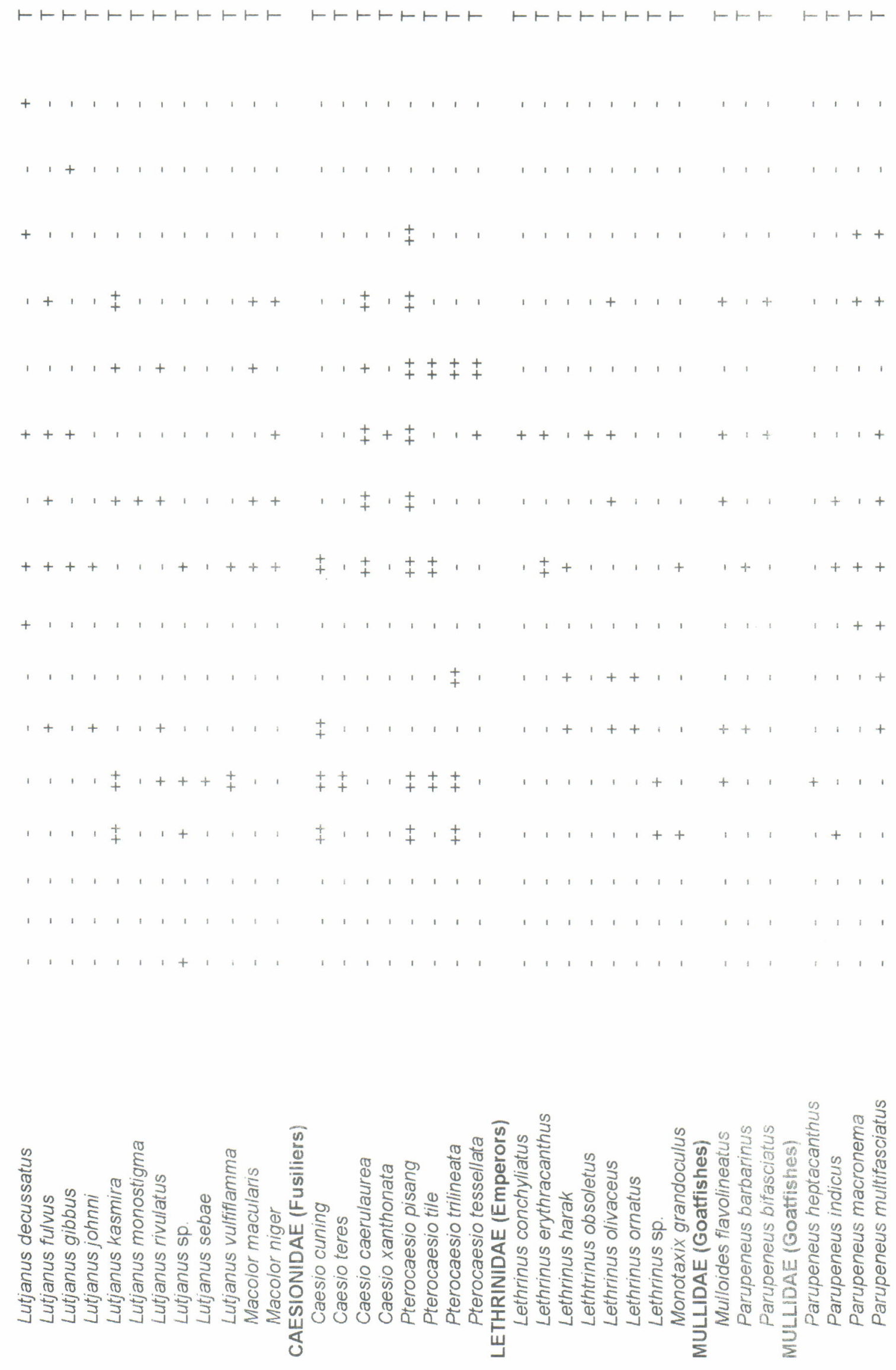


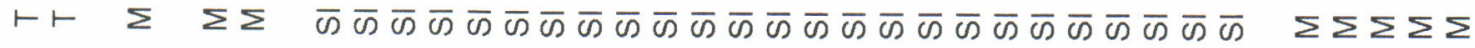

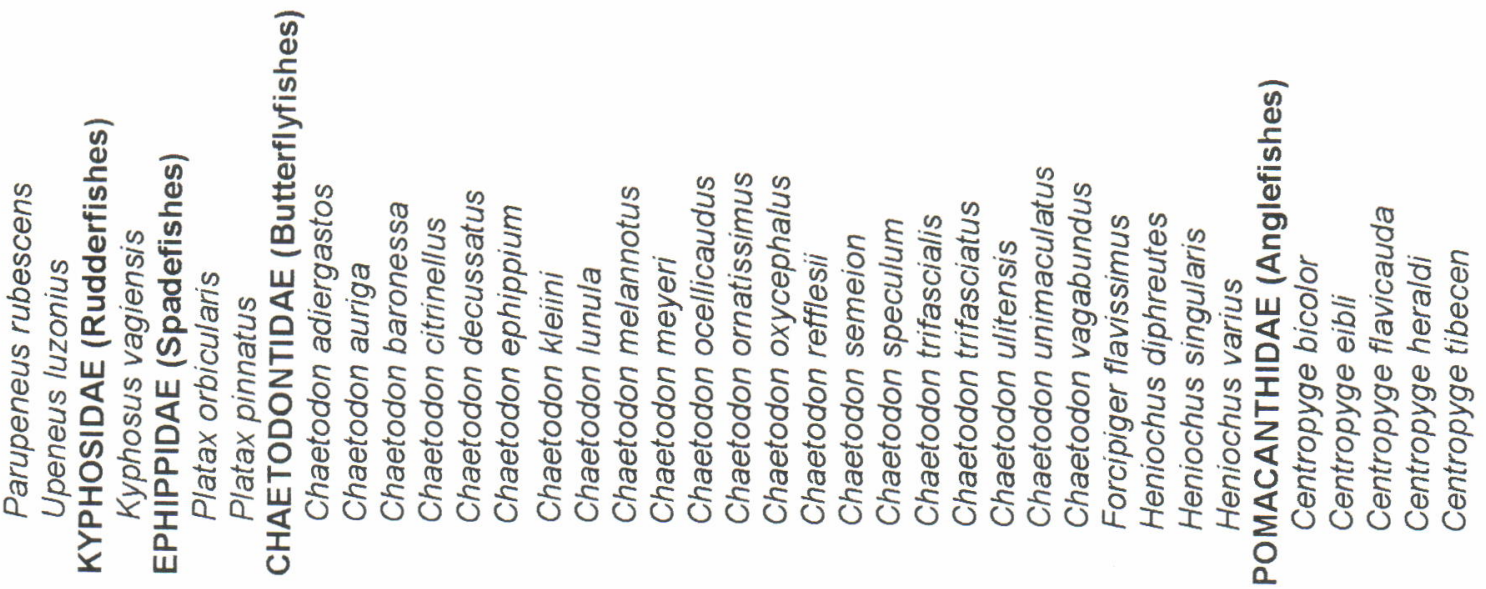



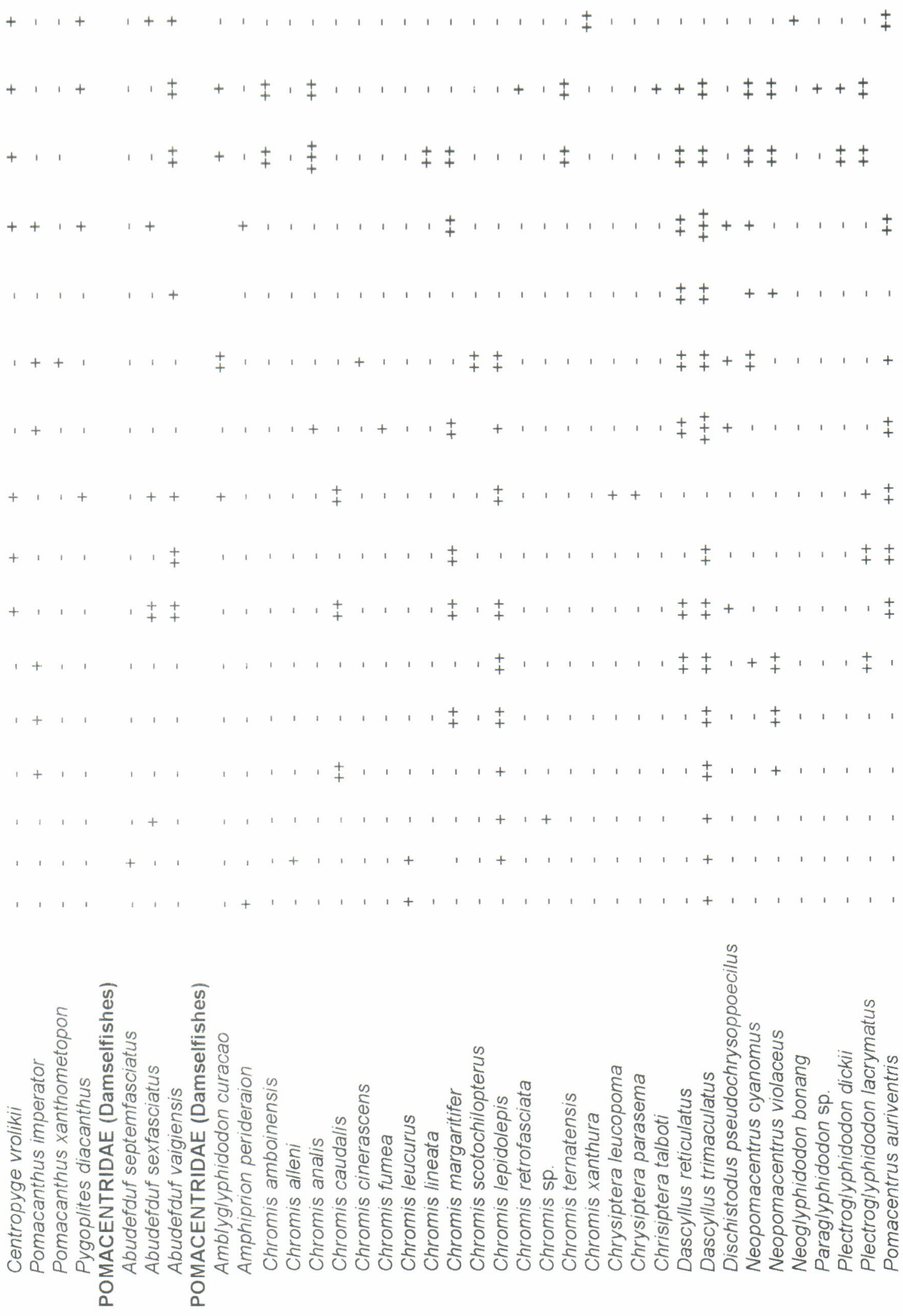


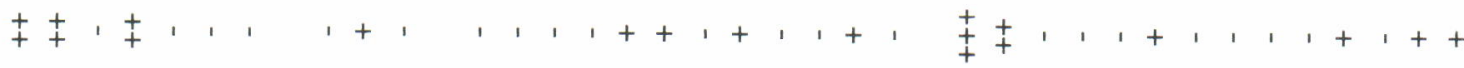

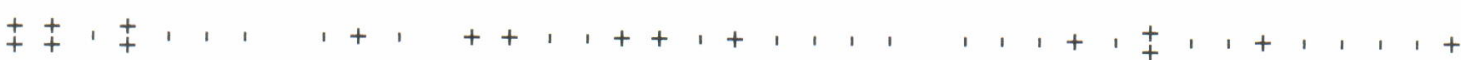
$++1,1,1,+1,1+++1,1+$
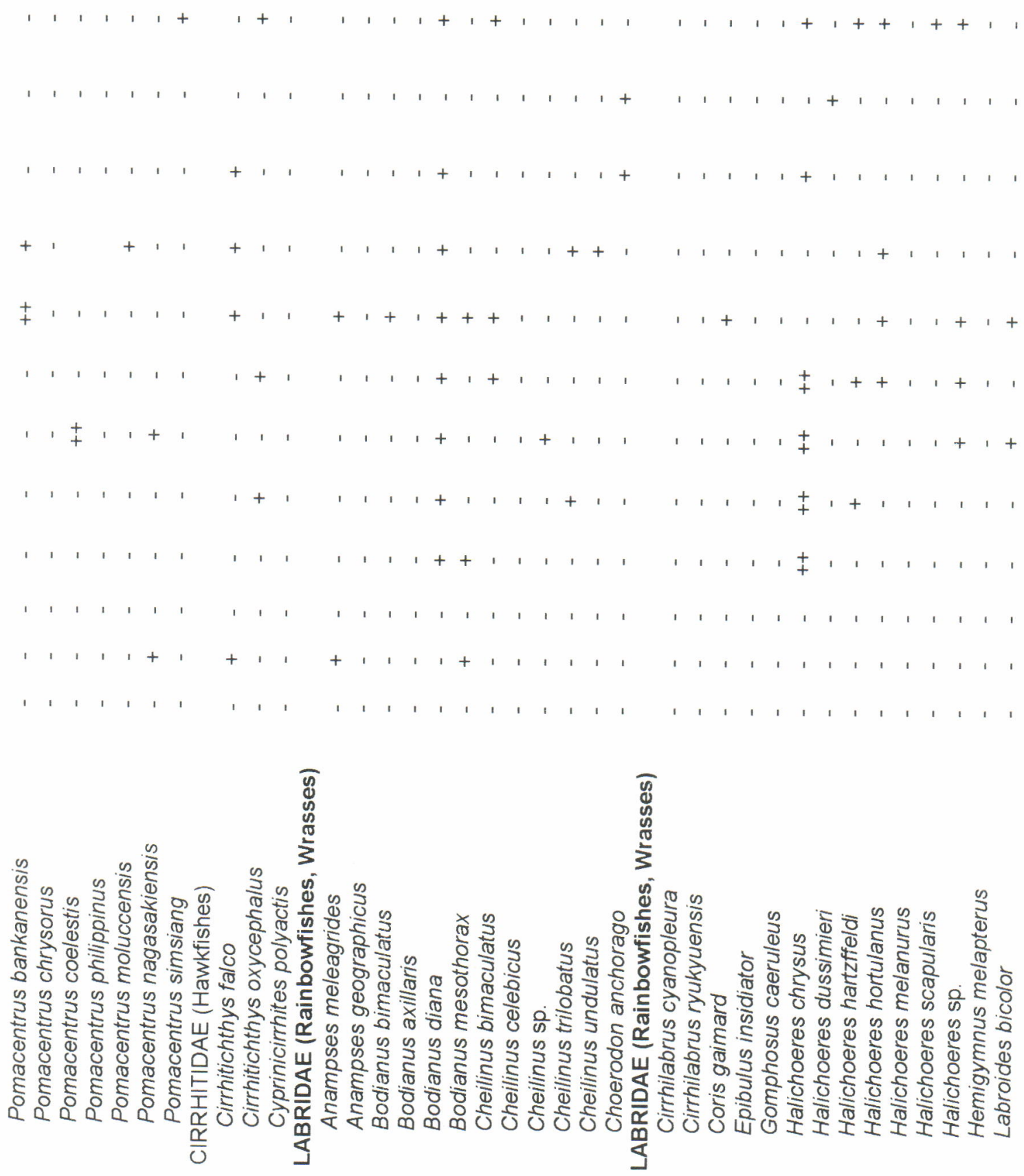
Isa Nagib Edrus and Suprapto

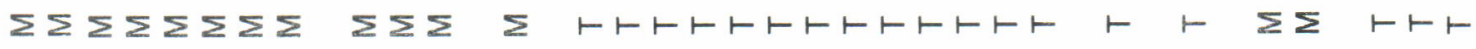

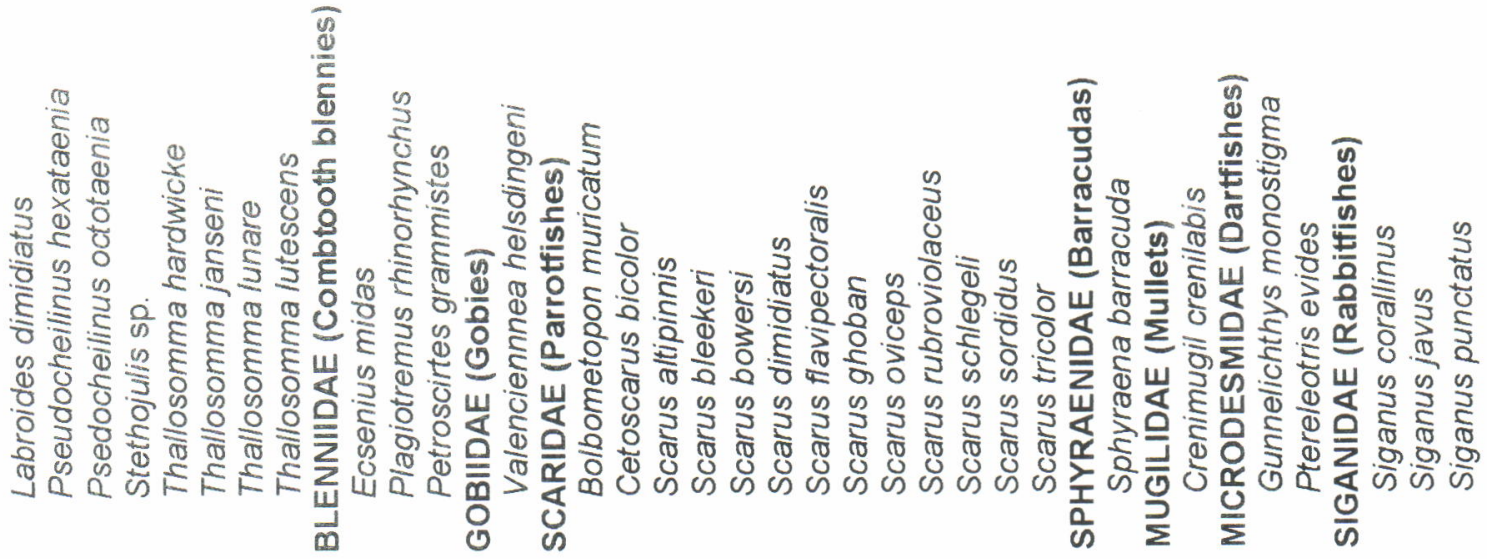




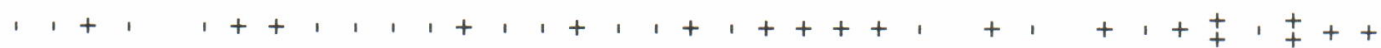

$1+1++1+++1+1,1+1++1+++1++1+1+1++$

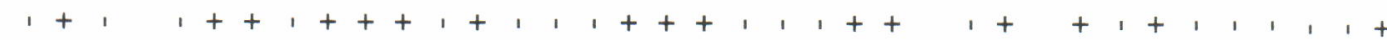

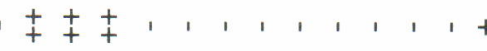

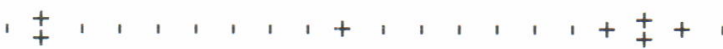

$++$

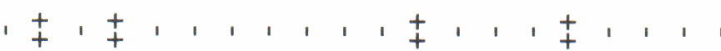

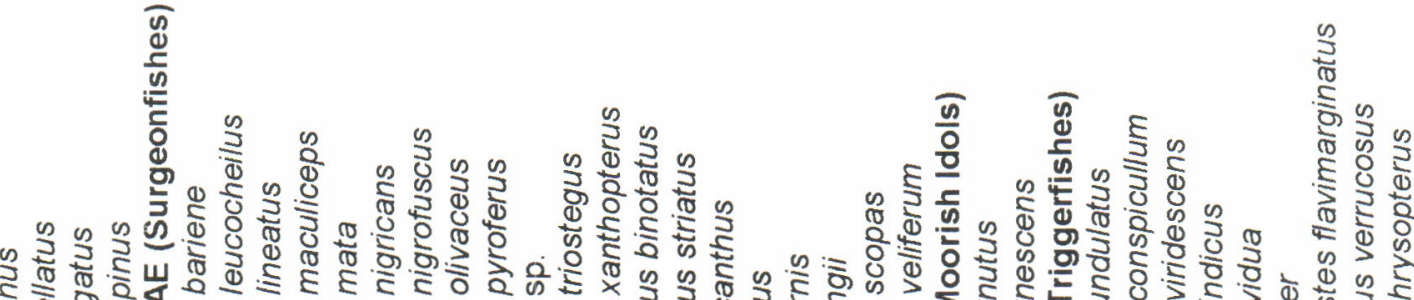

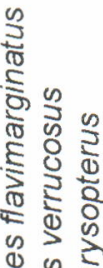

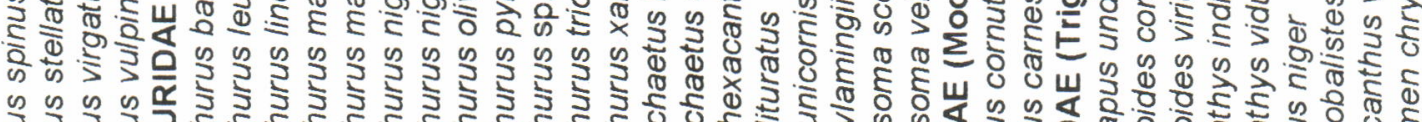
わ

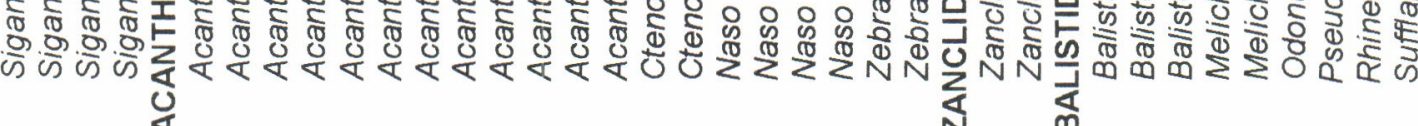




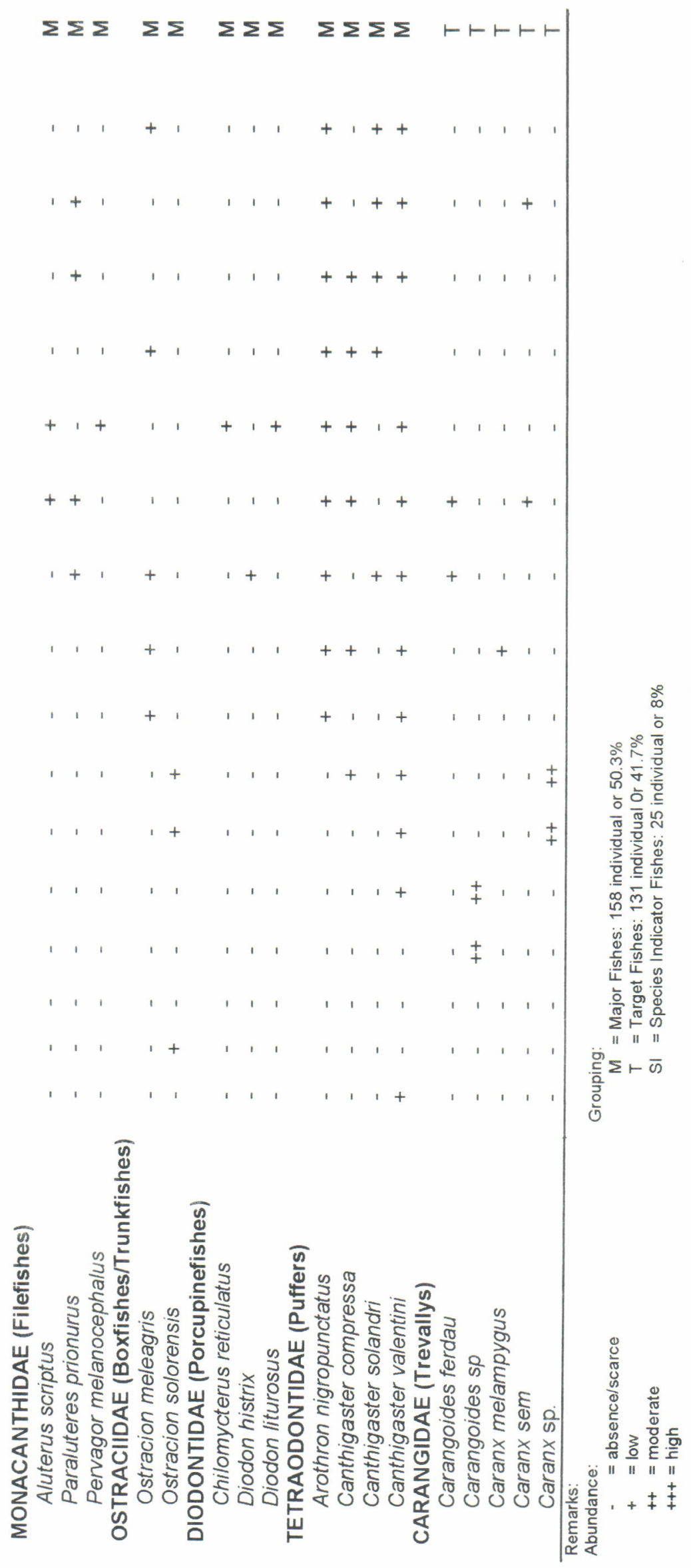

